\title{
OPTIMAL SHARE OF PRIVATISATION IN A PUBLIC MONOPOLY WITH UNIONISED WORKERS*
}

\section{Luciano Fantia (iD, Domenico Buccellab}

\begin{abstract}
In a monopoly industry with firm-union wage bargaining, we show that it is optimal to privatise a share of the public firm. The optimal privatisation share increases with the union's higher bargaining power and/or wage-orientation and, when the latter is large, full privatisation becomes socially optimal. Interestingly, the optimal privatisation share is the highest (lowest) when the government attributes a medium-low (low and high) weight to the workers' welfare, notably when the union's bargaining power and/or wageorientation are sufficiently high. This may be counterintuitive because it implies that leftwing governments (with a weak and moderate union) tend to privatise more greatly.
\end{abstract}

Keywords: Optimal privatisation, unionised monopoly, right-to-manage bargaining JEL Classification: H44, J51, L12, L33

\section{Introduction}

A well-established result in the economic literature is that social welfare is always higher under a public monopoly than under a private one when the labour market is unionised. In this paper, we show that a strategic partial (and even full) privatisation - that is, the policy of transforming a public firm into a mixed (public-private) firm, where the government chooses optimally the share to be sold to the private sector - is welfare-enhancing.

The main results of the paper are as follows. Firstly, the higher the privatisation share, the lower the negotiated wages. Secondly, the output of the public firm is independent

a Department of Economics and Management, University of Pisa, Italy

E-mail: 1fanti@ec.unipi.it

b Department of Economics, Kozminski University, Poland

E-mail: buccella@kozminski.edu.pl

* We are extremely grateful to the Editorial Board of Politická Ekonomie and two anonymous referees for their extensive and useful comments and suggestions that have helped us to improve substantially the quality and clarity of this paper. Usual disclaimers apply.

The authors do not report any potential conflict of interest.

Data sharing availability statement: Data sharing is not applicable to this article as no new data were created or analysed in this study. 
of the government's concern for workers' welfare: loosely speaking, the "political" orientation of the government is irrelevant for consumers. Thirdly, more interestingly, the two "unionisation" measures adopted in the present work - i.e., the union bargaining power and its wage-orientation - work in favour of privatisation: the higher the degree of unionisation, the more likely privatisation may ensure social welfare higher than state ownership. Fourthly, in the presence of a weak and/or employment-oriented union, a large privatisation share is, rather paradoxically, preferred when the government considers the workers' welfare highly while, in the presence of a strong and/or wage-oriented union, the optimal degree of privatisation is higher when the government assigns a medium-low weight to the workers' welfare in its objective. Those findings are confirmed qualitatively in a model with managerial delegation. However, the presence of a manager in a public monopoly who negotiates with the union requires a government that is adequately "leftwing" oriented and, moreover, leads to an optimal privatisation share lower than without delegation. The rationale for this result is that managerial delegation is itself a tool to restrain excessive (from a social perspective) wage demands.

The remainder of the paper is organized as follows. Section 2 presents a review of the related literature. Section 3 introduces the basic ingredients of the model and derives the main results. Section 4 concludes the paper with some remarks and proposals for future research.

\section{Literature Review}

Over the recent decades, the analysis of privatisation has produced a vast body of theoretical literature (see, e.g., the excellent survey by Bös, 1991). In particular, De Fraja and Delbono $(1987,1989)$ have shown that (1) in a mixed oligopoly, the privatisation of welfaremaximizing public firms may improve social welfare; and (2) a public monopoly is always more efficient than a private monopoly.

The recent literature on mixed oligopolies has highlighted that in a game-theoretic framework, the degree of privatisation can be used as a government's strategic decision. In a strategic environment in which a public firm competes with private firms, the government can better enhance social welfare through a partial privatisation of the publicly-owned firm (e.g., Matsumura, 1998; Bennett and Maw, 2003; and Fujiwara, 2007). ${ }^{1}$

On the other hand, Maw (2002) examines the empirical evidence of the adoption of a partial degree of privatisation of state-owned enterprises (SOEs) - and its justification

1 Subsequently, the welfare implications of partial privatisation in mixed oligopolies have been investigated in various extended contexts, for instance, in the case of free-entry markets by Matsumura and Kanda (2005), Brandão and Castro (2007) and Wang and Chen (2010), and production technology issues by Bárcena-Ruiz (2012). 
in the cases of economies in transition such as post-communist ones. In the same vein, Bjørnskov and Potrafke (2011) analyse how the government's ideology has affected the privatisation process in the post-communist countries. Other empirical studies have been conducted with regard to Italian SOEs (Asquer, 2011, for public utilities and Clò et al., 2016, as regards the top ten Italian SOEs) and in a worldwide perspective (Kowalski et al., 2013; Clò et al., 2015).

However, this literature abstracts from the context of public firm wages determined on unionised labour markets, which has been dealt with theoretically by De Fraja (1993), Ishida and Matsushima (2009), and Fanti and Buccella (2016), and empirically by Haskel and Szymanski (1993).

In the presence of a unionised labour market, De Fraja (1993) analyses wage negotiations (the right-to-manage model, RTM) in a public and a private monopoly as well as in a mixed duopoly (a public firm competing with a private one). The author shows that the wages paid in public firms can be higher than in their private counterparts because of different objective functions, and the oligopolistic interdependence between private and public producers when they operate in the same industry. Privatisation has an ambiguous, and limited, impact on the wages paid by the privatised firm. On the other hand, it increases the wages paid by the privatised firm's competitor, whose profits increase after privatisation (unless its union has a strong bargaining power) while, after privatisation, the product price increases and the utilities of unions decrease.

Fanti and Buccella (2016) study the choice of the union-monopoly bargaining agenda, i.e., only wage negotiations (RTM) vs wages and employment negotiations (the efficient bargaining model, EB), and compare the outcomes in the public and private sectors. They show that, regardless of the public or private nature of the monopoly, RTM is always preferred to both simultaneous and sequential EB. Moreover, contrary to the standard result that a public monopoly always leads to higher welfare than a private one, the authors also show that a fully privatised monopoly can guarantee social welfare higher than state ownership provided that (1) the government values the workers' well-being highly; and (2) the labour union has a strong bargaining power and is wage-sensitive.

In a unionised mixed duopoly, Ishida and Matsushima (2009) study the regulatory framework of public institutions. They focus on a wage regulation imposed on the public firm, which has crucial welfare implications because of two opposite strategic effects. On the one hand, the wage regulation increases competition on the downstream market; on the other hand, it reduces competition on the upstream market. The impact on welfare is ambiguous and depends on the degree of product differentiation. In contrast to common wisdom, the authors also show that conceding civil servants the right to bargain collectively can harm them because of their excessively high wage claims. 
Haskel and Szymanski (1993) also develop a manager-workforce bargaining model to explain employment and wage levels when the government privatises public firms, liberalising markets. Then, collecting data for the period 1972-1988 on 14 UK companies which were publicly owned in 1972, the authors find that: (1) as a consequence of the change to more commercial objectives, employment in public firms fell; and (2) privatisation slightly affected wage levels; however, if the public firm lost market power, then the wage decrease was more relevant.

Nonetheless, the above-mentioned works do not consider the issue of strategic optimal privatisation. On the other hand, Brown et al. (2010) and Earle and Shpak (2019) test empirically the effect of privatisation on wage and employment levels in transition economies and show that they are almost never at lower levels after domestic privatisation and generally higher in the case of foreign privatisation.

Among those issues, the privatisation policy gathers momentum in several Central and Eastern European countries that have been undergoing a transition path from a prior command, state-led economy in the direction of a liberal one. In such countries, it has been common to privatise several sectors of the economy in the post-communist decades, and this process has been mainly motivated by the creation of the private sector "from scratch", and often the privatised enterprises were not monopolies or oligopolies. ${ }^{2}$

However, looking closer at the experience of the Central and Eastern Europe, an OECD report (2014) notifies that, notwithstanding ambitious privatisation plans that have been launched in the last decades, in countries such as the Czech Republic, Estonia, Hungary, Latvia, Lithuania, Poland and Slovenia, there are a few industries, typically recognised of "strategic importance" such as transportation, coal and chemicals and utilities (electricity, gas and telecommunications), in which the incidence of large SOEs is still predominant (see Table 1). Hahm (2013) reports that Croatia presents the most noticeable figures, having 584 SOEs that account for $68 \%$ of the national GDP.

In the public sector, those countries are characterised by a significant presence of unionised workers compared to Continental Europe. For instance, Armingeon (2006, p. 11) asserts that "...collective bargaining by unions in post-communist countries is to a similar extent protected by statutory rules, as it is the case in the west. This protection is strongest in the Mediterranean countries, and weakest in the Anglo-Saxon democracies. The level of protection of collective bargaining in the post-communist nations

2 In the words of Estrin (2007, p. 14), "The most impressive feature of privatisation in the transition economies has been the speed and scale at which it occurred. The reforming governments of the late 1980s and early 1990s managed successfully to transfer the huge state-owned sector into largely private hands in a time period of hardly more than a decade and to do so they had to use innovative privatisation methods." 
corresponds to that of the Continental nations". Indeed, Waddington (2005) reveals that in 2002, the union density in Slovenia was $41 \%$ but the public sector proportion was $76.2 \%$; for Slovakia, the figures were $35.4 \%$ and $70.9 \%$, respectively; for Latvia $20 \%$ and $82.1 \%$; the Czech Republic reported $25.1 \%$ and $44.5 \%$, respectively; Hungary $19.9 \%$ and 70.3\%. Moreover, Fulton (2013) reports that in Croatia, a 2010 survey found union density to be $68 \%$ in the public sector, but only $17 \%$ in the private sector, while in Poland, a survey published in 2012 found that employees of state-owned companies and institutions were three times more likely to be union members than those working in the private sector.

\section{Model}

The model builds on De Fraja (1993) and Fanti and Buccella (2016). Let us consider an industry in which a single firm produces goods for the market. The linear inverse demand function the monopolist faces is

$$
p=a-q
$$

where $p$ and $q$ denote the price and quantity of goods, respectively.

Table 1: Number of SOEs and their employment rate, selected Central and Eastern European countries.

\begin{tabular}{l|c|c}
\hline Country & $\begin{array}{c}\text { Number } \\
\text { of SOEs }\end{array}$ & $\begin{array}{c}\text { Rate over total } \\
\text { dependent } \\
\text { employment }\end{array}$ \\
\hline Czech Republic & 125 & $4 \%$ \\
\hline Estonia & 53 & $4.5 \%$ \\
\hline Hungary & 371 & $5 \%$ \\
\hline Latvia & 74 & $>2 \%$ \\
\hline Lithuania & 137 & $>2 \%$ \\
\hline Poland & 326 & $>2 \%$ \\
\hline Slovenia & 39 & $10 \%$ \\
\hline
\end{tabular}

Source: OECD (2014)

By assuming a standard constant returns-to-scale technology in the unique input, labour, that is $q=B L$, where $L$ is the employment and $B$ an exogenous index of the labour productivity, the profit function of the monopolist is 


$$
\pi=(a-q) q-A w q,
$$

where $w$ is the wage paid per unit of output, and $A$ is the reciprocal of $B$. We assume that (1) the monopolist's workforce is fully unionised and (2) the union members are sufficiently many to meet the monopolist's labour demand.

The union's utility function is,

$$
V=A\left(w-w^{\circ}\right) L
$$

which is a specific case of the Stone-Geary utility function (e.g., Pencavel, 1984, 1985). In (3), $w^{\circ}$ is the reservation (or competitive) wage, and $\theta$ is a parameter capturing the union's sensitivity to wages. Values of $\theta<(>) 1$ denote that the union is less (more) wage-oriented and more (less) employment-oriented. When $\theta=1$, the union becomes rent-maximising (i.e., the union maximises the total rent). When $\theta=1$ and $w^{\circ}=0$ the union is wage bill-maximising. For simplicity, we fix $A=1$ and $w^{\circ}=0 .^{3}$ Thus, given that $q=L,(3)$ can be rewritten as:

$$
V=w^{\theta} q .
$$

The social welfare is expressed as a weighted sum of consumers' surplus (CS), profit and the union's utility. Following De Fraja (1993) and Fanti and Buccella (2016), the social welfare function is supposed to have the following analytical expression

$$
S W=C S+\pi+m V^{\circ},
$$

where $V^{\circ}$ is the wage bill value of the union. ${ }^{4}$ Thus, following De Fraja (1993), from (5) one observes that the public firm is assumed to maximise the weighted sum of consumer surplus, profit and the union's utility, where the weight attached to the union's utility is exogenously given and captured by the parameter $m \in(0,1]$.

Two reasons can be addressed to justify that the weight on the union's utility is less than one. The first is algebraic: one can easily see that this assumption is necessary to obtain an equilibrium. In fact, as Ishida and Matsumura (2009, p. 638) note, "[ ... w without this restriction, the public firm's union can unlimitedly raise its wage because the optimal output level

3 In an extension of the present model, while considering rent-maximising unions (i.e., $\theta=1$ ), we have relaxed those assumptions, allowing for both different productivity levels and positive reservation wages. Preliminary calculations show that our results are qualitatively robust to this model specification. In detail, it is observed that the higher the reservation wage and the lower the productivity, the larger the optimal share of privatisation. Moreover, a positive degree of privatisation can be optimal; however, it always reduces the union's utility. In this sense, privatisation can be optimal but not Pareto-superior. The results are available upon request from the authors.

4 Considering the union's wage bill or rent instead of the union's utility function in the definition of the social welfare function is common in the unionised oligopolistic industries literature.

For an in-depth theoretical explanation, see Zhao (2001) and Fanti and Buccella (2016). 
of the public firm is independent of the wage, which only affects the distribution of wealth between the firm and the union. Since no firms, including public entities, possess an unlimited amount of resources, it is natural to assume that the public firm faces a restriction of this kind."

The second is political: as De Fraja (1993, p. 460) states, “[...] there may be political reasons why an increase in union utility is not considered as positive an occurrence as an increase in the profit accruing to the Treasury or as a reduction in the price of the good." Otherwise, $m$ can be set at the value of one; however, in this case, the bar-gaining problem has to meet a budget constraint regarding the public firm profits (e.g., Choi, 2012).

Following Matsumura and Kanda (2005) and Fujiwara (2007), and adapting their approach to the case of a monopoly, we assume that a fraction $z$ of the ownership of the public monopolistic firm may be privatised (e.g., we have the case of a private monopoly when $z=1$, while it is that of a public monopoly when $z=0$; for values $z \in[0,1]$ the public monopoly is partially privatised). That is, the monopolist's objective function, $M$, is the following:

$$
M=z \pi+(1-z) S W=\pi+(1-z)\left(C S+m V^{\circ}\right) .
$$

Note that, in some cases, at the level of privatisation for which social welfare as a whole is the highest, profits may be negative; however, opportune lump-sum redistributions ensure the participation also of the private shareholders. ${ }^{5}$

As known, the two bargaining models most commonly adopted in the trade-union economics are: (1) the right-to-manage model (RTM) (e.g., Nickell and Andrews, 1983), in which wages are bargained between firms and unionised labour; yet, once wages are fixed, firms retain the right to choose employment; and (2) the efficient bargaining model (EB), which establishes that unionised labour and firms bargain - either simultaneously, or sequentially - over wages and employment (more plausibly, working hours)

5 The objective function of the monopolistic firm in (6) implicitly assumes that each shareholder (either public or private) participates on profit according to his/hers ownership share $z$. Therefore, the share on the monopoly profit of each shareholders is linear in $z$. However, in reality, there are several non-linearities in the distribution of profit among shareholders related to the ownership level. As the private shareholder exceeds $50 \%$ of the ownership share, she/he obtains the control over the whole enter-prise and is able to grab larger share of profit than $z$, e.g. via transfer pricing. In an extension, we have considered the case of $z^{2}$ for a value of $m=0.5$. Our preliminary calculations (available upon request) show that the qualitative results of the model are confirmed; however, two noteworthy quantitative differences arise. First, while with a linear istribution of profits, for precise values of the bargaining power of the union $(b=0)$ and its wage orientation $(\theta=0)$ the optimal privatization share is zero, with a quadratic distribution there is always a strictly positive privatization share. Second, the optimal privatization share with quadratic distribution is around $10 \%$ higher than with linear distribution. We speculate that increasing values of $m$ will magnify those effects. An indept investigation on this issue is left for further research. In the history of CEECs privatisation one could find several cases of spoiled privatisation (see e.g. in the Czech Republic the case of OKD, IPB). 
(e.g., McDonald and Solow, 1981; Manning, 1987a, b). This work assumes an RTM arrangement between the monopolist and the union, in line with the findings of Fanti and Buccella (2016), who show that, in the cases of public and private monopolies, the bargaining parties always prefer RTM to simultaneous and sequential EB.

We set a three-stage game. At the first stage, the government chooses the optimal share of privatisation of the monopoly by maximising its social welfare function (5). At the second stage, the wage is determined through the RTM bargain. At the third stage, the monopolistic firm chooses the output maximising its objective function in (6). The game is solved, as usual, by backward induction.

The proposed timing of the game mirrors the assumptions concerning which strategic decision adjustment occurs more frequently than the others. As usual, among industrial organisation practitioners, the long-term strategic decisions are set at the earlier stages of the game. Therefore, given that the market (output) subgame decisions are considered the more frequently revised (production plan revisions can take place several times within a year), those are generally assumed at the last stage of the game. The stipulation of wage contracts occurs less frequently than the output adjustments: in fact, in Europe, the duration of wage contracts is typically two or three years. Consequently, wage negotiations are assumed at the second stage. The government's decision about the privatisation share is, in the proposed framework, the most long-term strategic choice, and therefore set at the first stage. ${ }^{6}$

At stage 3, solving the profit maximisation problem of the monopolist firm, we get the following output function for a given wage

$$
q(w)=\frac{a-w[1-m(1-z)]}{1+z} .
$$

Remark 1: If the wage is exogenous, the weight of workers' welfare in the social welfare function raises the quantity produced by the monopoly.

At stage 2 of the game, under right-to-manage negotiations, the monopolist-union bargaining unit selects $w$ to maximize the following generalized Nash product,

$$
\underbrace{\max }_{\text {w.r.t. w }} N=(M)^{1-b}(V)^{b}=\left[(a-q) q-w q+(1-z)\left[\frac{\beta q^{2}}{2}+m(w q)\right]\right]^{1-b}\left(w^{\theta} q\right)^{b},
$$

6 Theoretically, one can conceive an alternative timing for this game, that is, that wage negotiations take place at the first stage, and then the government, at the second stage, chooses the privatisation level. This would affect the outcomes of the game. Intuitively, if wages are negotiated at the first stage, then the union anticipates the government's privatisation decision and lowers the wage demand. As a consequence, we speculate that the optimal share of privatisation should decrease under this timing. However, a comprehensive analysis is beyond the scope of this paper, and it is left for future research. 
where $b$ represents the union's bargaining power. Maximising (8) with respect to $w$, after substitution of (7) in (8), we obtain

$$
w=\frac{a b \theta}{z m \phi+(1-m) \phi},
$$

where $\phi=2-b(1-\theta)$. By using (9), we obtain the equilibrium output (as a function of $z$ ):

$$
q(z)=\frac{(2-b) a}{(1+z) \phi} .
$$

Remark 2: By simple inspection of (9) and (10), we note that, as expected, wages always increase (reduce) the weight of workers' welfare in the social welfare function (the share of privatisation), while quantities are always reduced by the share of privatisation and are independent of the weight of workers' welfare in the social welfare function.

The latter finding means that the weight of workers' welfare in the social welfare function increases wages to the extent that the positive direct effect on quantity given in Remark 1 and the indirect negative effect via the wage increase on quantity exactly cancel each other, so that with unionised wages the quantity produced by the public firm is not influenced by the concerns of government for the workers' welfare. From Remark 2, it follows that, as expected, privatisation (the concerns of government for it) reduces (increases) the workers' welfare.

By using (9) and (10), the other equilibrium outcomes of interest are obtained (as a function of $z$ ):

\section{Figure 1: Plot of the optimal privatization share $s^{*}$ as a function of the of the union's preference parameter $(\theta)$ and bargaining power of the union $(b)$, for specific values of $m$.}

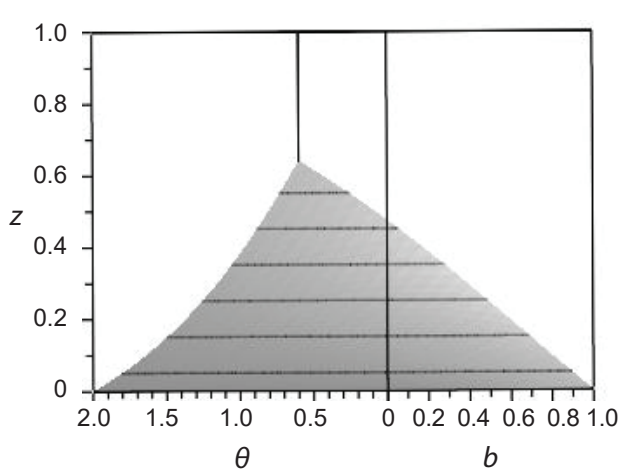

Optimal privatisation share, $m=\frac{1}{4}$

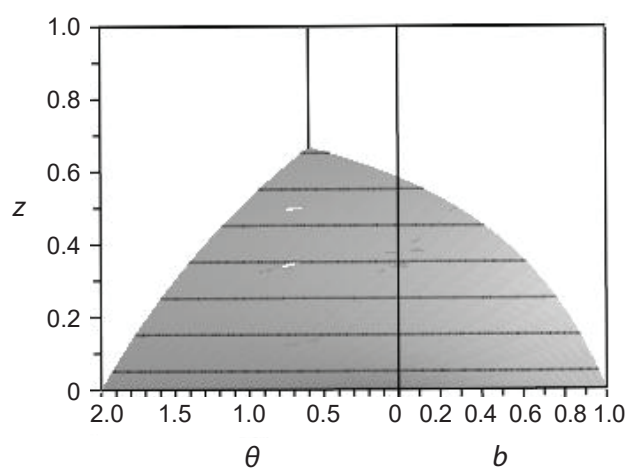

Optimal privatisation share, $m=\frac{1}{2}$

Source: Authors' own calculations 


\section{Figure 2: Plot of the optimal privatization share $s^{*}(m)$ for given values of the union's} preference parameter $(\theta)$ and union's bargaining power $(b)$.
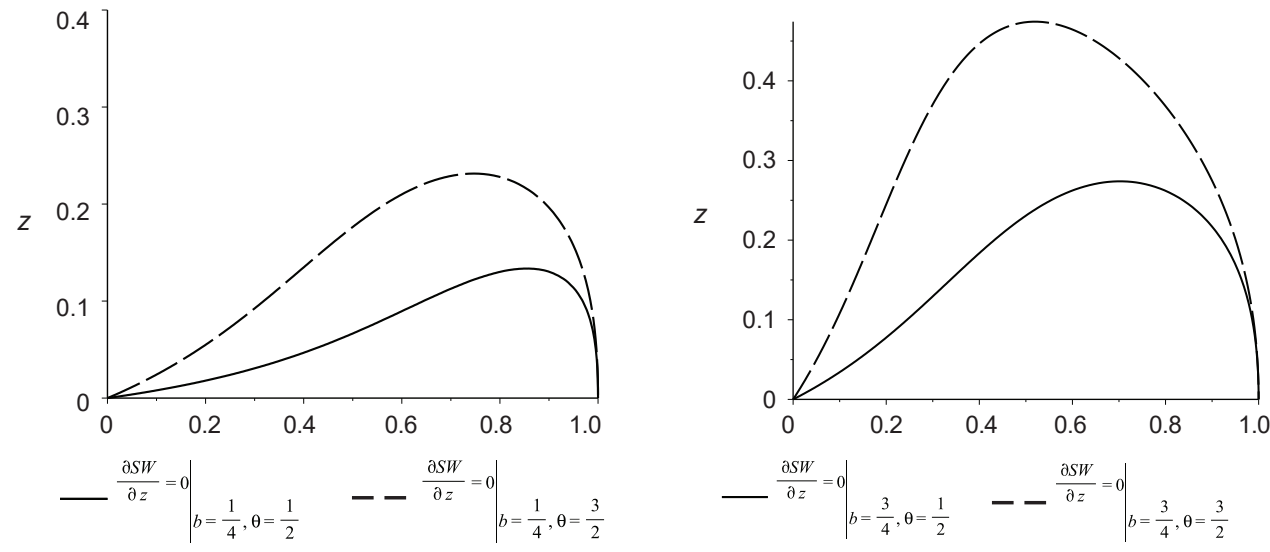

Source: Authors' own calculations

$$
\begin{aligned}
& \pi(z)=\frac{(2-b) a^{2}\left[z^{2}(b m(\theta-1)+2 m)-b m(\theta-z)-z(b+2(m-1))\right]}{[1-m(1-z)](1+z)^{2} \varphi^{2}} \\
& S W(z)=\frac{(2-b) a^{2}\left\{2 m^{2} z^{2} \phi-m z[2-(1+2 \theta) b]+(1+2 z-m)(2-b)\right\}}{2[1-m(1-z)](1+z)^{2} \phi^{2}} .
\end{aligned}
$$

Finally, at the first stage, the government chooses the optimal privatisation share by maximising the social welfare function. The FOC condition is given by:

$$
\frac{\partial S W(z)}{\partial z}=0 \Leftarrow\left\{\begin{array}{l}
z m^{2} \phi\left(1+z^{2}\right)+m z(1+z m)[(2-\theta) b-4] \\
-b m \theta(1-m)+z(2-b)(1+2 m z)
\end{array}\right\}=0 .
$$

Since (13) is analytically intractable, we resort to the numerical simulation to obtain the following result:

Result 1: The higher the union's bargaining power and/or wage-orientation, the larger the optimal share of privatisation.

Corollary: If unions are weak and/or employment-oriented (strong and/or wage-oriented) the optimal share of privatisation is larger when the interest of the government for the workers' welfare is higher (medium-low). 
A graphical representation of Result 1 and the Corollary is given in Figures 1 and 2. The intuition behind Result 1 is that, for any given level of the government's care for workers' welfare, the privatisation may be used "strategically" to dampen excessive (from a social welfare point of view) wage claims by workers. As a matter of fact, a positive degree of privatisation may be optimal but it always reduces the union's utility: in this sense, privatisation can be optimal but cannot be Pareto-superior at the same time.

As regards the Corollary, the rationale for this finding can be explained as follows. In the case of a fully private monopoly, the monopolist selects employees considering only the firm's labour demand. On the other hand, a public monopolist, given its broad objective function, hires a larger number of workers than the private monopoly. In the case of privatisation, the private shareholders of a mixed private-public firm would act following the logic of the private monopolist, therefore tending to reduce employment and, consequently, the output of the industry. This implies an increase in the final price of the goods and, therefore, of the size of the monopoly rent that the labour union can capture. Therefore, in line with the findings of Fanti and Buccella (2016), a left-wing oriented government, rather counter-intuitively, should be in favour of (full or partial) privatisation of state-owned companies.

\subsection{Extension: managerial delegation in the public firm}

The ground-breaking works of Vickers (1985), Fershtman (1985), Fershtman and Judd (1987) and Sklivas (1987) (hereinafter referred to as VFJS) have proposed in the literature the strategic use of incentive contracts in oligopolies, in which decisions are delegated to managers. According to VFJS, owners in oligopolies seek to motivate their managers via compensation contracts (i.e., with a bonus which depends on a weighted sum of profits and sales, defined as "sales delegation"), with the objective to conduct aggressive behaviour to gain a competitive advantage on the market. Thus, the individual ownermanager relationships are investigated within the context of rival owner-manager pairs.

It is evident that such a strategic effect does not exist in the case of a monopoly. As Fershtman and Judd (1987, p. 928) notice, "[I]n the case of a monopoly firm, the optimal incentive structure is obviously the regular principal-agent problem since there are no opponents and, in the absence of risk-sharing and asymmetric information considerations, such an owner will motivate his manager to maximize profits." That is, in the contract theory, the finding that optimal incentive schemes should use information other than profits can only arise if there is uncertainty and/or imperfect information. However, Fanti and Buccella (2017) have shown that such incentive schemes can be used in the absence both of uncertainty and/or informative imperfections and of a context 
of rivalrous ownership-manager pairings: in fact, a monopolist can use managerial delegation as a device to weaken the wage demands via a penalisation of output (employment) in the manager's bonus scheme.

While the issue of managerial delegation in a public monopoly is tackled in this paper for the first time, to the best to our knowledge, such an issue has been treated in an oligopolistic context, and without unionisation, by the early work of Barros (1995) and by many subsequent contributors, for instance by Chirco et al. (2014), who study how the strategic choice of price/quantity as the market variable is affected by different organisational structures (managerial or entrepreneurial) of the public and the private firm.

This subsection extends the basic model presented above to the case in which the government (the owner of the public firm), delegates output decisions to a manager. Following Meccheri and Fanti (2014) and Fanti and Buccella (2017), the bonus of the manager is proportional to

$$
U=M+s q,
$$

where $M$ is the public monopolist's objective function and the weight on output, $s$ is a positive (negative) number if the government incentivises (disincentivises) the manager's choice of quantity. Note that, with regard to the determination of the manager's payoff, the standard assumption of the managerial delegation theory is that the firm's owner selects the fixed component (salary) of the manager's compensation, so that the manager gets exactly his or her opportunity costs. In the current paper, and without loss of generality, the opportunity costs are normalized to zero. Consequently, this implies that the manager's pay-off does not affect the level of social welfare.

With managerial delegation, the game presents an additional stage, in which the manager maximizes her/his own utility. At stage 4, maximisation of (14) leads to the following quantity:

$$
q(w)=\frac{a+s-w[1-m(1-z)]}{1+z} .
$$

It can be noted directly that Remark 1 also applies in the presence of managerial delegation. At stage 3 of the game, under right-to-manage negotiations, the manager-union bargaining selects $w$ to maximize this Nash product

$$
\underbrace{\max }_{w . r . t .} N=(U)^{1-b}(V)^{b}=\left[(a-q-w+s) q+(1-z)\left[\frac{q^{2}}{2}+m(w q)\right]\right]^{1-b}\left(w^{\theta} q\right)^{b},
$$

where $b$ is, as before, the union's strength. Substitution of (15) into (16) and subsequent maximisation with respect to $w$, leads to 


$$
w=\frac{(a+s) b \theta}{z m \phi+(1-m) \phi} .
$$

Making use of (17), the equilibrium output (as a function of $z$ and $s$ ) is

$$
q(z, s)=\frac{(2-b)(a+s)}{(1+z) \phi}
$$

Remark 2 still holds true under managerial delegation.

By using (17) and (18), it is observed that the public monopoly objective is (as a function of $z$ and $s$ ):

$$
M(z, s)=\frac{(a+s)(2-b)\{2(a+s)-b[a+s(2 \theta-1)]\}}{(1+z) \phi^{2}} .
$$

Due to the mechanisms described in Remarks 1 and 2, it can be noticed immediately that the public monopolist's objective function is not affected by the government's concerns for the workers' welfare.

At stage 2, the government fixes the value of the manager's bonus. Maximisation of (19) yields

$$
s=-\frac{a b \theta}{2-b(1-2 \theta)}<0,
$$

that is, the manager is penalised for output (employment) because the manager's bonus increases wages (see (17)) and, therefore, the government sets a "negative" bonus in the public manager retribution scheme to curb the union's wage demand. In other words, managerial delegation can be introduced as a strategic device to reduce wage claims (Fanti and Buccella, 2017).

Finally, at the first stage, the government selects the optimal privatisation share by maximising the social welfare function. Given (17) and (18), the social welfare function is

$$
S W(z, s)=\frac{\left[\begin{array}{l}
2[1-m(1-z)][a z+0.5(a-s)] \\
+b\{s(0.5-\theta)-0.5 a-z(a+s \theta) \\
\left.\left[m\left(s(\theta-0.5)+0.5 a+(a+s)(0.5+\theta)+a(\theta-1) z^{2}\right)\right]\right\}
\end{array}\right]}{[1-m(1-z)](1+z)^{2} \phi^{2}} .
$$

Substituting (20) into (21), the FOC condition is given by:

$$
\frac{\partial S W(z)}{\partial z}=0 \Leftarrow\left\{\begin{array}{l}
z^{3} m^{2}[1+b(\theta-0.5)]+m\left[\left(z^{2}+0.5(1-m)\right)(\phi-m(2-b))+\right. \\
b \theta(0.5-m)(1-m)]
\end{array}\right\}=0 .
$$


Given that (22) is analytically intractable, we perform numerical simulations as before to obtain the following result:

Figure 3: Plot of the optimal privatization share $s^{*}$ under managerial delegation as a function of the union's preference parameter $(\theta)$ and bargaining power of the union (b), for specific values of $m$

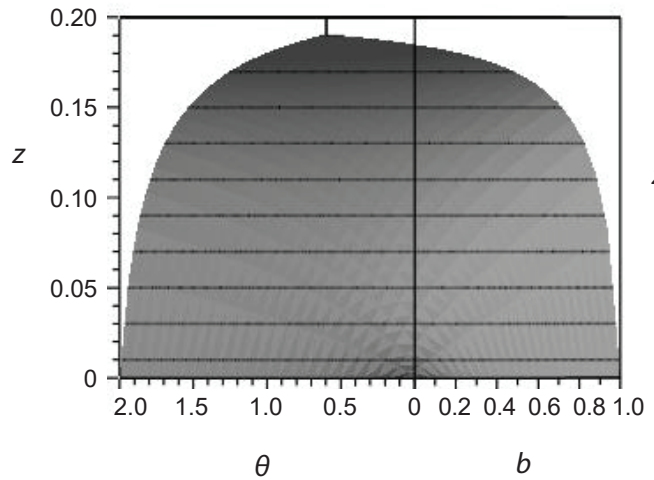

Optimal privatisation share with managerial delegation, $m=\frac{3}{4}$

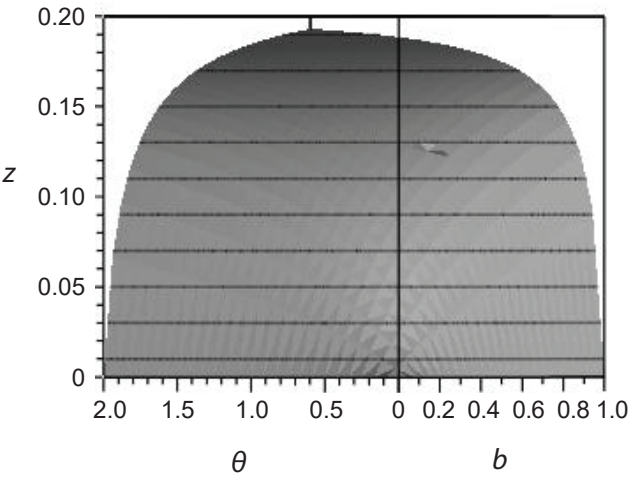

Optimal privatisation share with managerial delegation, $m=\frac{4}{5}$

Source: Authors' own calculations

Figure 4: Plot of the optimal privatization share $s^{*}(m)$ under managerial delegation for given values of the union's preference parameter $(\theta)$ and union's bargaining power $(b)$
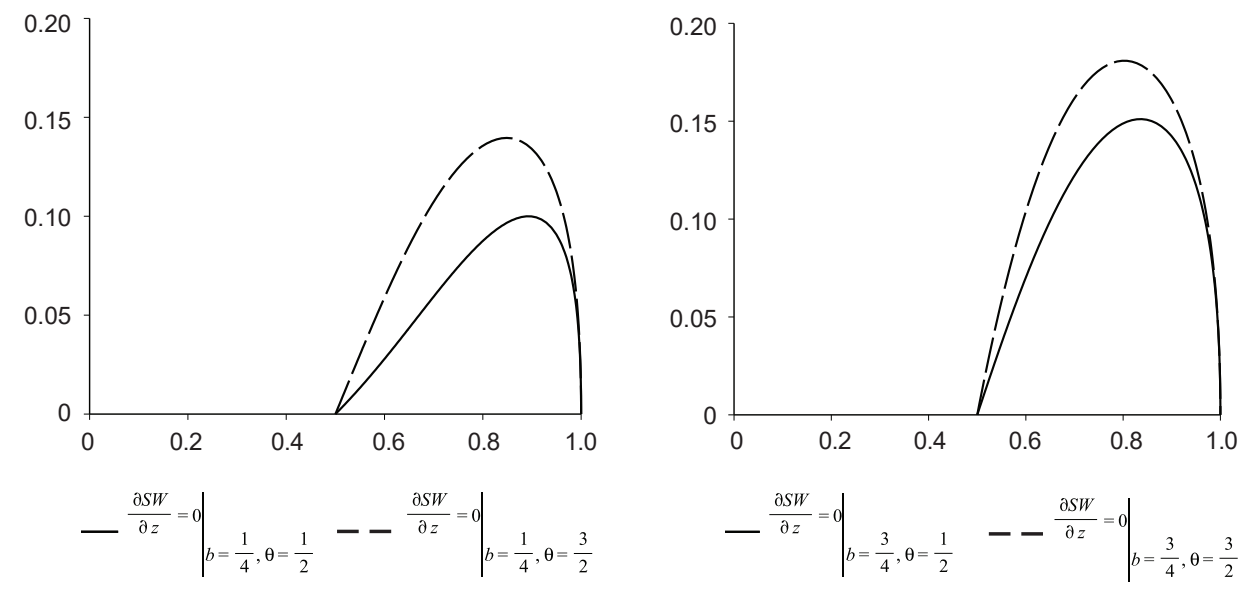

Source: Authors' own calculations 
Result 2: Like in the case without managerial delegation, the higher the union's bargaining power and/or union's wage-orientation, the larger the optimal share of privatisation; however, privatisation is optimal only if the government adequately consider the workers' welfare $m \geq 0.5$. Moreover, given the negative effect on wage demands of the penalty for output in the manager's payment scheme, ceteris paribus, the optimal share of privatisation is substantially lower than without managerial delegation.

Corollary: Provided that $m \geq 0.5$, if unions are weak and/or employment-oriented (strong and/or wage-oriented) the optimal share of privatisation is larger when the government's concern for the workers' welfare is high, though not extremely high (medium-high).

A graphical representation of Result 1 and the Corollary is given in Figures 3 and 4 . Result 2 reveals that, provided that $m \geq 0.5$, for any given level of the government's care for workers' welfare, privatisation can be used as a further strategic tool to moderate the workers' wage claims. The qualitative conclusions that can be derived are substantially identical to the case of no delegation; however, quantitatively, our results seem to suggest that a properly designed manager payment scheme is more effective than privatisation to reduce the union's wage bargaining outcome in the public firm.

\section{Conclusions}

Common wisdom believes that, while in oligopolistic contexts privatisation of a public firm may also be efficient, the social welfare is always higher under a public monopoly than under a private one. Since the issue of privatisation is high on the political agenda especially in post-communist countries, and monopolistic firms are often unionised, the present paper has investigated whether and how the common wisdom may be challenged in the presence of labour union-firm relations (with an RTM bargaining agenda). We show that the union's power as well as the union's preferences towards wages and employment matter for the relative efficiency of private or public ownership of firms. Moreover, their interaction with the weight that the government attributes to the welfare of workers is important to determine the optimal share of privatisation of public firms. The key results of the paper are as follows.

Firstly, the larger the privatisation share, the lower the wages. Secondly, the quantity produced by a public firm is independent of the government's concern for workers' welfare: loosely speaking, consumers are indifferent to the "political" orientation of the government. Thirdly, more interestingly, the two measures of the degree of "unionisation" in the model - i.e., the union's bargaining power and wage-orientation - work for privatisation: the higher the degree of unionisation, the more likely privatisation could guarantee social welfare higher than state ownership. Fourthly, in the presence of a weak and/or 
employment-oriented union, greater privatisation, rather paradoxically, is preferred when the government takes the workers' welfare highly into consideration. Otherwise, in the presence of a strong and/or wage-oriented union, the optimal degree of privatisation is higher when the government attributes a medium-low weight to the workers' welfare.

The results of the paper are far from being exhaustive. The current model is based on a series of simplifying assumptions. For example, the demand schedule and the production technology present specific, linear functional forms. An immediate research step would be the introduction in the analysis of a decreasing returns-to-scale technology to check the robustness of the current findings. A further suitable extension is to consider a mixed duopoly with product and price competition in the presence of differentiated products. In addition, the introduction of R\&D investments and consumption externalities are promising fields of investigation.

\section{References}

Armingeon, K. (2006). Trade Unions and Industrial Relations in Post-Communist Nations. A Comparison with Established Democracies. University of Berne, Department of Political Science. Chicago Paper for the Conference of Europeanists.

Asquer, A. (2011). Liberalization and Regulatory Reform of Network Industries: A Comparative Analysis of Italian Public Utilities. Utilities Policy, 19(3), 172-184, https://doi. org/10.1016/j.jup.2011.04.001

Bárcena-Ruiz, J. C. (2012). Privatization When the Public Firm is as Efficient as Private Firms. Economic Modelling, 29(4), 1019-1023, https://doi.org/10.1016/j.econmod.2012.03.011

Barros, F. (1995). Incentive Schemes as Strategic Variables: An Application to a Mixed Duopoly. International Journal of Industrial Organization, 13(3), 373-386, https://doi.org/10.1016/0167-7187(94)00461-a

Bennett, J., Maw, J. (2003). Privatization, Partial State Ownership, and Competition. Journal of Comparative Economics, 31(1), 58-74, https://doi.org/10.1016/s0147-5967(02)00008-2

Bjørnskov, C., Potrafke, N. (2011). Politics and Privatization in Central and Eastern Europe. Economics of Transition, 19(2), 201-230, https://doi.org/10.1111/j.1468-0351. 2010.00404.x

Bös, D. (1991). Privatization: A Theoretical Treatment. Oxford: Clarendon Press. ISBN 9780198283690.

Brandão, A., Castro, S. (2007). State-owned Enterprises as Indirect Instruments of Entry Regulation. Journal of Economics, 92(3), 263-274, https://doi.org/10.1007/s00712-007-0286-y

Brown, D. J., Earle, J. S., Telegdy, Á. (2010). Employment and Wage Effects of privatisation: Evidence from Hungary, Romania, Russia and Ukraine. The Economic Journal, 120(545), 683-708, https://doi.org/10.1111/j.1468-0297.2009.02300.x

Chirco, A., Colombo, C., Scrimitore, M. (2014). Organizational Structure and the Choice of Price versus Quantity in a Mixed Duopoly. The Japanese Economic Review, 65(4), 521-542, https://doi.org/10.1111/jere.12046 
Choi, K. (2012). Price and Quantity Competition in a Unionised Mixed Duopoly: The Cases of Substitutes and Complements. Australian Economic Papers, 51(1), 1-22, https://doi.org/10.1111/j.1467-8454.2012.00419.x

Clò, S., Del Bò, C. F., Ferraris, M., et al. (2015). Public Enterprises in The Market for Corporate Control: Recent Worldwide Evidence. Annals of Public and Cooperative Economics, 86(4), 559-583, https://doi.org/10.1111/apce.12093

Clò, S., Di Giulio, M., Galanti, M. T., et al. (2016). Italian State-Owned Enterprises After Decades of Reforms: Still Public? Economia Pubblica, 3, 11-49, https://doi.org/10.3280/ ep2016-003002

De Fraja, G. (1993). Unions and Wages in Public and Private Firms: A Game-theoretic Analysis. Oxford Economic Papers, 45(3), 457-469, https://doi.org/10.1093/oxfordjournals.oep. a042102

De Fraja, G., Delbono, F. (1987). Oligopoly, Public Firm and Welfare Maximization: A Game Theoretic Analysis. Giornale degli Economisti e Annali di Economia, 46(7/8), 417-435.

De Fraja, G., Delbono, F. (1989). Alternative Strategies of a Public Enterprise in Oligopoly. Oxford Economic Papers, 41(2), 302-311, https://doi.org/10.1093/oxfordjournals.oep. a041896

Earle, J., Shpak, S. (2019). Impact of Privatization on Employment and Earnings. IZA World of Labor, 93(2), https://doi.org/10.15185/izawol.93

Estrin, S. (2008). Privatization Impacts in Transition Economies, in Durlauf, S. N., Blume, L. E., eds., The New Palgrave Dictionary of Economics. London: Palgrave Macmillan, https://doi.org/10.1057/978-1-349-95121-5_2547-1

Fanti, L., Buccella, D. (2016). Privatisation or State Ownership When Labour Market is Unionised? Folia Oeconomica Stetinensia, 16(1), 21-36, https://doi.org/10.1515/ foli-2016-0002

Fanti, L., Buccella, D. (2017). Manager-Union Bargaining Agenda Under Monopoly and with Network Effects. Managerial and Decision Economics, 38(6), 717-730, https://doi.org/10.1002/mde.2809

Fershtman, C. (1985). Managerial Incentives as a Strategic Variable in Duopolistic Environment. International Journal of Industrial Organization, 3(2), 245-253, https://doi.org/10.1016/0167-7187(85)90007-4

Fershtman, C., Judd, K. L. (1987). Equilibrium Incentives in Oligopoly. American Economic Review, 77(5), 927-940.

Foster, N. A., Henry, S. G., Trinder, C. (1984). Public and Private Sector Pay: A Partly Disaggregated Study. National Institute Economic Review, 107, 63-73, https://doi.org/10.1177/002795018410700108

Fujiwara, K. (2007). Partial Privatization in a Differentiated Mixed Oligopoly. Journal of Economics, 92(1), 51-65, https://doi.org/10.1007/s00712-007-0267-1

Fulton, L. (2013). Worker Representation in Europe. Labour Research Department and ETUI. ETUI. Available at: http://www.worker-participation.eu/National-Industrial-Relations 
Hahm, H. (2013). Look at Poland and South Korea - They Saved Themselves Through

Public Sector Reforms. Washington, D.C.: The World Bank [2013-11-18]

Available at: http://www.worldbank.org/en/news/opinion/2013/11/18/

croatia-and-the-example-of-poland-and-s-korea

Haskel, J., Szymanski, S. (1993). Privatization, Liberalization, Wages and Employment: Theory and Evidence for the UK. Economica, 60(238), 161-182, https://doi.org/10.2307/2554587

Ishida, J., Matsushima, N. (2009). Should Civil Servants be Restricted in Wage Bargaining?

A Mixed-duopoly Approach. Journal of Public Economics, 93(3-4), 634-646, https://doi.org/10.1016/j.jpubeco.2008.11.004

Manning, A. (1987a). An Integration of Trade Union Models in a Sequential Bargaining Framework. The Economic Journal, 97(345), 121-139, https://doi.org/10.2307/2233326

Manning, A. (1987b). Collective Bargaining Institutions and Efficiency. European Economic Review, 31(1-2), 168-176, https://doi.org/10.1016/0014-2921(87)90028-6

Matsumura, T. (1998). Partial Privatization in Mixed Duopoly. Journal of Public Economics, 70(3), 473-483, https://doi.org/10.1016/s0047-2727(98)00051-6

Matsumura, T., Kanda, O. (2005). Mixed Oligopoly at Free Entry Markets. Journal of Economics, 84(1), 27-48, https://doi.org/10.1007/s00712-004-0098-z

Maw, J. (2002). Partial Privatization in Transition Economies. Economic Systems, 26(3), 271-282, https://doi.org/10.1016/s0939-3625(02)00047-x

McDonald, I. M., Solow, R. M. (1981). Wage Bargaining and Employment. American Economic Review, 71(5), 896-908.

Meccheri, N., Fanti, L. (2014). Managerial Delegation Contracts under Centralized Unionization. Managerial and Decision Economics, 35(1), 51-66, https://doi.org/10.1002/mde.2606

Pencavel, J. H. (1984). The Trade-off between Wages and Employment in Trade Union Objectives. Quarterly Journal of Economics, 99(2), 215-231, https://doi.org/10.2307/1885523

Pencavel, J. H. (1985). Wages and Employment under Trade Unionism: Microeconomic Models and Macroeconomic Applications. Scandinavian Journal of Economics, 87(2), 197-225, https://doi.org/10.2307/3439822

Sklivas, S. D. (1987). The Strategic Choice of Managerial Incentives. RAND Journal of Economics, 18(3), 452-458, https://doi.org/10.2307/2555609

Vickers, J. (1985). Delegation and the Theory of the Firm. The Economic Journal, 95(380a), 138-147, https://doi.org/10.2307/2232877

Waddington, J. (2005). Trade Union Membership in Europe-The Extent of the Problem and the Range of Trade Union Responses. ETUI-REHS Research Department. A Background Paper for the ETUC/ETUI-REHS Top Level Summer School, Florence, 1-2 July 2005.

Wang, L. F. S., Chen, T.-L. (2010). Do Cost Efficiency Gap and Foreign Competitors Matter Concerning Optimal Privatization Policy at the Free Entry Market? Journal of Economics, 100(1), 33-49, https://doi.org/10.1007/s00712-010-0117-4

Zhao, L. (2001). Unionization, Vertical Markets, and the Outsourcing of Multinationals. Journal of International Economics, 55(1), 187-202, https://doi.org/10.1016/ s0022-1996(01)00090-3 